\title{
Women's Perception Concerning Health Care in the Post-Partum Period: A Meta-Synthesis
}

\author{
Maria Suely Correa, Katia Virginia Feliciano, Evelyne Nascimento Pedrosa, \\ Ariani Impieri Souza \\ Instituto de Medicina Integral Professor Fernando Figueira-IMIP, Recife, Brazil \\ Email: ariani@imip.org.br
}

Received 21 March 2014; revised 20 April 2014; accepted 27 April 2014

Copyright (C) 2014 by authors and Scientific Research Publishing Inc.

This work is licensed under the Creative Commons Attribution International License (CC BY). http://creativecommons.org/licenses/by/4.0/

\section{(c) (i) Open Access}

\section{Abstract}

This meta-synthesis presents the results of qualitative studies on puerperal perception concerning woman's care in the post-partum period. Four databases were researched using keywords such as "postnatal care" (or) "postpartum period", (and) "care", "women", "perception", "qualitative research", "women's health services", "community health services", "allied health personnel", "primary health care", resulting in 9 articles for analysis. Six themes were identified: interpersonal relationship, information, communication, attending the necessities, service organization and other supports. Results report mainly on the unsatisfactory professional care for women, appreciating the form of dealing with promptness and the timing to be attended; trust; content, coherence and the way to inform; clarification of doubts; friendly conversation and clinical assistance. The professional workload was restricted on postpartum period care quality. There were gaps found in clinical practice and in dialogical communication and information on women's health necessities.

\section{Keywords}

Post-Partum Care, Qualitative Research, Meta-Synthesis, Women's Health, Needs Assessment

\section{Introduction}

The puerperium is a puerperal pregnancy cycle period in which the woman experiences biological, psychological and socio-cultural transformation, with a strong impact on their health and quality of life [1] [2]. In this phase, it is the responsibility of the health services to integrate technical knowledge and the ability to welcome 
and detect early physical and emotional changes, preventing and treating diseases that are specific causes of morbidity and maternal death, as well as support the woman in her process of mental reorganization as to the bonding of her baby, breastfeeding, body changes, sexuality and contraception [3].

This is a privileged moment to prioritize woman's demands, appreciate anxieties, fears, desires and necessities, and seek to reconcile the diversity of knowledge and meanings [1]. The enlarged apprehension and the enlarged apprehension and prudent of health necessity requires dialogical communication as a vital tool in health practices [4]. The willingness to engage in a dialog enables an intersubjectivity relationship, in which the professional who has a technical scientific knowledge, modifies herself as a subject and modifies her action in taking care of others [5].

This article has an objective to synthesize the results of qualitative studies on puerperal perception concerning care for the woman in the post-partum period. It is expected to achieve a greater understanding of puerperal necessities, desires and interests in bringing subsidies to improve public policies and health care practices based on the attention to the woman.

\section{Method}

This synthesis of qualitative studies uses a meta-ethnographic approach by Noblit and Hare [6], comprised on three phases: 1) systematic review of the literature; 2) critical evaluation on the quality of the articles and 3) synthesis of the results.

\subsection{Systematic Review of the Literature}

The included articles carried out the following criteria: 1) to investigate women's perspective at 18 years and older concerning health care in the post-partum period; 2) constituting as original studies that used qualitative methods and 3) have been published in English, Spanish or Portuguese from January 1990 to December 2011. The studies excluded were on post-abortion care, psychiatric disorders in the post-partum period and those focused on clinical complications on puerperium and breastfeeding.

The electronic bibliographic research included PubMed, LILACS, SciELO and CINAHL databases, respecting their search strategies. The descriptors "post natal care" or "post-partum period", were combined with: "care”, "women”, "perception”, “qualitative research”, "women’s health services”, “community health services”, "allied health personnel”, "primary health care”, and excluded the descriptors "post-partum depression”, "breastfeeding" and "hemorrhage". There also were a free search and in the study references to find articles that were not located in the beginning of the research.

Initially, 8.562 articles were identified. Two independent reviewers filtered this material to select 122 articles by the titles in which 53 were excluded for duplicity, obtaining 69 articles for reading summaries. This reading enabled to exclude 46 articles (quantitative studies, studies with mixed quantitative predominance, focused on post-partum home experience, cultural adaptation or in access), leaving 23 articles to be read thoroughly. Of these, eight were excluded (quantitative method, parents and family members as subjects of the study and focusing informal support), 15 articles were left for critical quality evaluation. At this stage, six articles were excluded: one was impossible to obtain a full text and five had insufficient descriptions of the study design and analysis. The uncertainties and disagreements in all the stages were discussed by four reviewers. Finally, nine articles were selected for meta-syntesis (Figure 1).

\subsection{Critical Quality Evaluation of the Studies}

The summary review on quality criteria led to employing an adapted version of the consolidated criteria for reporting qualitative research-COREQ [7], although one of the studies had also used an observation as a research technique [8]. The choice of this instrument occurred to detail its questionings, providing a more complete information exchange among the reviewers in an attempt to improve the reliability of the judgments. The COREQ is composed of 32 grouped questions into three domains: 1) research team and reflexivity; 2) study design and 3) analysis and result. The adaptation corresponded to an increase in domain 2, three questions on historical-social context, technical research and ethical aspects.

Considering the criteria for each domain, only three studies presented their theoretical-methodological fundamental [8]-[10] and four mentioned some aspects in relation to researcher-participants [8] [11]-[13]. Four studies have notified how many researchers analyzed the data [11] [13]-[15], but all studies have informed the set 


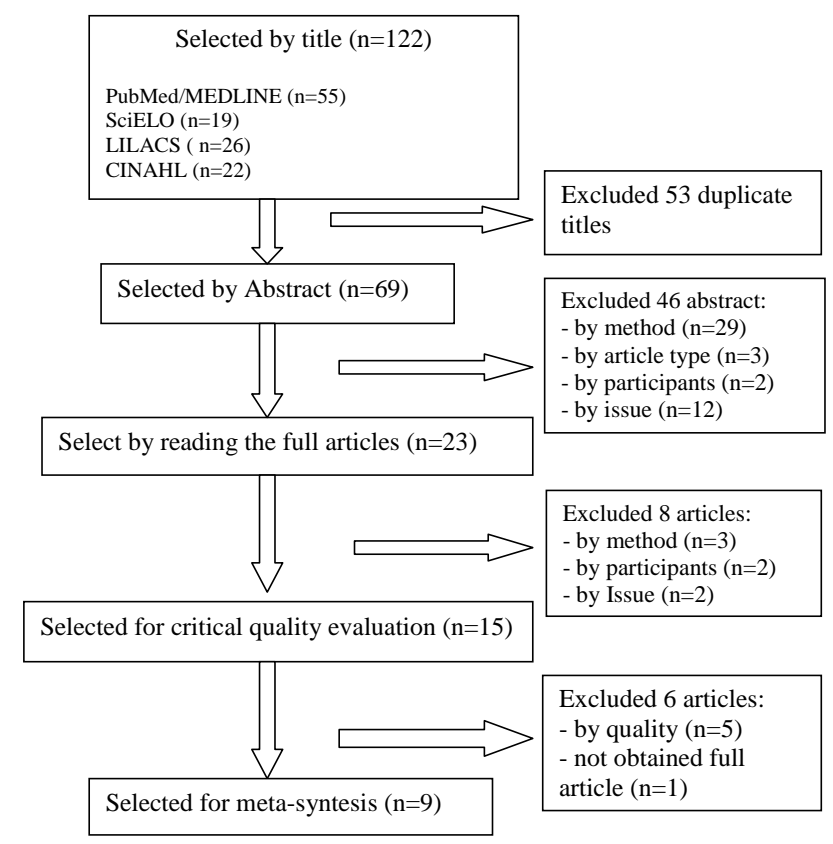

Figure 1. Search process and study selection.

of categories identified and the nature of deductive or inductive analysis and also have ceased to provide information on any criterion. We followed the guidance by Sandelowski \& Barroso [16] and Campbell et al. [17], about the necessity to evaluate by applying careful judgment in order to distinguish between superficial mistakes which make the findings invalid. As other researchers [18]-[20], we assessed only the explanation and completeness of the information contained in the publications.

\subsection{Synthesis of the Results}

The interpretative synthesis of the results, based on meta-ethnography by Noblit and Hare [6], was achieved by reciprocal translation and chronologically arranged articles: the key concepts or categories which constitute of themes from the first article, evidenced by analysis on thematic content were considered as reference and each subsequent article was compared to it and other previous articles. During the process, other concepts appeared and needed feedback interpretation. A careful and repeated reading for each article aimed to ensure the registration of all present concepts and carried out the systematic identification of similarities and differences of concepts and themes through the studies.

The concept of the construct in the first order (the participants' understanding from the original studies), in the second order (interpretation of attending the participants by the authors in these studies), in the third order (synthesis in the first and second order of the constructs on a new theory about the phenomenon) was used to interpret and reinterpret the studies. Six key themes were developed from the constructs in the first and second order: interpersonal relation, information, communication, attending the necessities, service organization and other supports. There was a similarity in the interpretations of the independent reviewers, but differences in the details were decided up on the discussion.

The synthesis of knowledge obtained on the main aspects of post-partum care, developed from the constructs in the first and second order, is being presented as a "line of arguments" consisted by five constructs in the third order that is interpenetrate: personal expectations, solidarity network, professional sphere, organizational sphere and structured social contexts.

\section{Results}

\subsection{Description of the Studies}

The included studies were conducted in Europe (Switzerland, Finland, and England), Brazil, Jordan and South 
Africa. Most of them had hospitals [8] [9] [11] [12] [15] and clinics [14] [21] as the main care scenario; and the midwife and members of the nursing team were responsible for the care [8] [10]-[15]. Half were developed in the hospital [8]-[10] [12] [15] and two did not inform the collecting location [11] [21]. Apart from a study that included a private service [14], all other contemplated in only public services. In eight studies the subjects were women and only in one puerperal and professionals [8]. An isolated [10]-[13] [15] or combined interview with focal group [9] and the observation [8] was the research technique most used. The analysis content was the analysis technique most applied [8] [10] [12] [15] [21], followed by other modalities of thematic analysis (Table 1).

\section{Theme Description}

Primary and secondary themes emerging from the included studies are described in Table 2.

\subsection{Interpersonal Relationship}

In all the studies, women appreciated the interpersonal relationship with health professionals, who were understood, based on experiences and expectations related to the way of treating and the willingness to attend. These two elements were fundamental for satisfaction or dissatisfaction derived from meeting the professional-user.

Table 1.Characteristics of the primaries studies.

\begin{tabular}{|c|c|c|c|c|c|c|c|c|}
\hline $\begin{array}{l}\text { Number } \\
\text { Article }\end{array}$ & Authors/Year & Country & Care Scenario & $\begin{array}{c}\text { Care } \\
\text { Responsible }\end{array}$ & $\begin{array}{l}\text { Collecting } \\
\text { location }\end{array}$ & $\begin{array}{c}\text { Technical of } \\
\text { data collection }\end{array}$ & $\begin{array}{c}\text { Subject } \\
(\mathrm{n}=\text { number of } \\
\text { subjects })\end{array}$ & Analysis \\
\hline [12] & $\begin{array}{c}\text { Almeida, M.S. } \\
\text { et al., } 2008\end{array}$ & Brazil & $\begin{array}{c}\text { Public } \\
\text { Maternity } \\
\text { (rooming) }\end{array}$ & Nursing team & Hospital & $\begin{array}{c}\text { Semi } \\
\text { structured } \\
\text { Interview }\end{array}$ & $\begin{array}{l}\text { Puerperal } \\
(\mathrm{n}=25)\end{array}$ & $\begin{array}{l}\text { Analysis } \\
\text { content } \\
\text { (Bardin) }\end{array}$ \\
\hline [13] & Bailey, S., 2010 & England & Domicile & Health visitor & Domicile & $\begin{array}{c}\text { Semi } \\
\text { structured } \\
\text { interview }\end{array}$ & $\begin{array}{l}\text { Puerperal } \\
(\mathrm{n}=7)\end{array}$ & $\begin{array}{c}\text { Thematic } \\
\text { networks } \\
\text { (Arttride- } \\
\text { Stirling) }\end{array}$ \\
\hline [15] & $\begin{array}{c}\text { Beake, S., et al., } \\
2010\end{array}$ & England & $\begin{array}{l}\text { Two public } \\
\text { maternities }\end{array}$ & $\begin{array}{l}\text { Midwifes/ } \\
\text { Nurses }\end{array}$ & Hospital & $\begin{array}{c}\text { Semi } \\
\text { structured } \\
\text { interview }\end{array}$ & $\begin{array}{l}\text { Puerperal } \\
(\mathrm{n}=20)\end{array}$ & $\begin{array}{c}\text { Analysis } \\
\text { content }\end{array}$ \\
\hline [11] & $\begin{array}{c}\text { Bondas-Salonen, } \\
\text { T.J., } 1998\end{array}$ & Finland & $\begin{array}{c}\text { Public } \\
\text { Maternity }\end{array}$ & Midwife & - & $\begin{array}{c}\text { Semi } \\
\text { structured } \\
\text { interview }\end{array}$ & $\begin{array}{l}\text { Puerperal } \\
(\mathrm{n}=9)\end{array}$ & $\begin{array}{c}\text { Thematic } \\
\text { analysis } \\
\text { (Colaizzi) }\end{array}$ \\
\hline [14] & $\begin{array}{l}\text { Butchart, W.A., } \\
\text { et al., } 1999\end{array}$ & South Africa & $\begin{array}{c}\text { Two clinical } \\
\text { postnatal cares } \\
\text { (one public and } \\
\text { one private) }\end{array}$ & Midwife & Clinics & Focal group & $\begin{array}{l}\text { Puerperal } \\
(\mathrm{n}=12)\end{array}$ & $\begin{array}{c}\text { Analysis } \\
\text { content } \\
\text { (Burnard) }\end{array}$ \\
\hline [8] & $\begin{array}{l}\text { Frei, I.A., et al., } \\
2011\end{array}$ & Switzerland & $\begin{array}{l}\text { Public } \\
\text { Maternity }\end{array}$ & $\begin{array}{l}\text { Midwifes/ } \\
\text { Nurses }\end{array}$ & Hospital & $\begin{array}{l}\text { Interview/ } \\
\text { Observation }\end{array}$ & $\begin{array}{c}\text { Puerperal } \\
\text { (n=10); } \\
\text { Nurse }(\mathrm{n}=4) ; \\
\text { Nurse student } \\
(\mathrm{n}=4) ; \\
\text { Midwife } \\
\text { student }(\mathrm{n}=2)\end{array}$ & $\begin{array}{c}\text { Thematic } \\
\text { analysis }\end{array}$ \\
\hline [21] & $\begin{array}{l}\text { Khalaf, I.A., } \\
\text { et al., } 2007\end{array}$ & Jordan & $\begin{array}{l}\text { Three centers } \\
\text { of attention to } \\
\text { maternal and } \\
\text { child health } \\
\text { (public) }\end{array}$ & $\begin{array}{c}\text { Health } \\
\text { professionals }\end{array}$ & - & Focal group & $\begin{array}{l}\text { Puerperal } \\
(\mathrm{n}=24)\end{array}$ & $\begin{array}{c}\text { Analysis } \\
\text { content }\end{array}$ \\
\hline [10] & $\begin{array}{l}\text { Rodrigues, D.P., } \\
\quad \text { et al., } 2006\end{array}$ & Brazil & $\begin{array}{c}\text { Public } \\
\text { Maternity } \\
\text { (rooming)/ } \\
\text { Domicile }\end{array}$ & Nursing team & $\begin{array}{l}\text { Hospital/ } \\
\text { Domicile }\end{array}$ & $\begin{array}{c}\text { Semi } \\
\text { structured } \\
\text { interview }\end{array}$ & $\begin{array}{l}\text { Puerperal } \\
(\mathrm{n}=7)\end{array}$ & $\begin{array}{c}\text { Analysis } \\
\text { content } \\
\text { (Bardin) }\end{array}$ \\
\hline [9] & $\begin{array}{c}\text { Soares, A.V.N., } \\
\text { et al., } 2003\end{array}$ & Brazil & $\begin{array}{l}\text { Public } \\
\text { Maternity } \\
\text { (rooming) }\end{array}$ & $\begin{array}{c}\text { Health } \\
\text { professionals }\end{array}$ & Hospital & $\begin{array}{l}\text { Interview/ } \\
\text { Focal group }\end{array}$ & $\begin{array}{l}\text { Puerperal } \\
(\mathrm{n}=23)\end{array}$ & $\begin{array}{c}\text { Discourse } \\
\text { analysis } \\
\text { (Taylor \& } \\
\text { Bogdan) }\end{array}$ \\
\hline
\end{tabular}


Table 2. Primary and secondary themes emerging from the included studies (article number mentioned in Table 1).

\begin{tabular}{|c|c|c|}
\hline THEMES & CONSTRUCTS OF THE FIRST ORDER & CONSTRUCTS OF THE SECOND ORDER \\
\hline $\begin{array}{l}\text { Interpersonal } \\
\text { relation }\end{array}$ & $\begin{array}{l}\text { Way to treat-attentive/inattentive, polite/rude, } \\
\text { patient/impatient, empathetic/impersonal, careful/careless, } \\
\text { sincere professional [8]-[11] [13] [14] [21]; supported } \\
\text { by/abandoned by, safe/unsafe, respected/disrespected, } \\
\text { revolted [9]-[12] [14] [15] [21]; Availability to } \\
\text { attend-took too long/attended quickly, had/lack of good } \\
\text { will, attended without hurry/in a hurry [8]-[12] [14] [15] } \\
\text { [21]; felt at ease/embarrassed to consult [9]-[12]; Factors } \\
\text { that influenced the relation-overworking [8]-[11] [13] } \\
\text { [15] [21]. }\end{array}$ & $\begin{array}{l}\text { The careful centered technique is a hospital routine [10] } \\
\text { [11]. Technical competence and ability to interact should } \\
\text { co-exist [9] [10] [12] [14]. Women want to be treated as } \\
\text { humans [9] [11] [12]. The overworking compromises the } \\
\text { professional-user interaction [9] [13]. The interpersonal } \\
\text { relation influences satisfaction with care [8] [9]. The } \\
\text { interpersonal relation is influenced by professional ability } \\
\text { and organization at work [8]. }\end{array}$ \\
\hline Information & $\begin{array}{l}\text { Information received-naval hygiene and general care for } \\
\text { the baby [9] [13] [21]; breastfeeding [8]-[11] [14] [21], } \\
\text { childcare [21]; liked/lack of important issues [8]-[11] [14] } \\
\text { [21]; reliable/unreliable on the professional's competence } \\
\text { [8] [9] [11] [14] [15]; sincere information [9]; contradicted } \\
\text { information [8] [10] [11] [14] [21]; seemed in favor [8] [9] } \\
\text { [13] [15] [21]; liked the lectures [9] and the educational } \\
\text { groups [21]; Lack/insufficient information-general care, } \\
\text { breastfeeding, baby illness, prevention on child illness [10] } \\
\text { [12] [14] [15]; ward routine [11] [15]; woman prescription } \\
\text { [12]; postpartum surgical [15] [21]; return to normal weigh } \\
\text { [21]; services referred to puerperium [10] [15]; puerperal } \\
\text { consultation and family planning [14] [21]; Information by } \\
\text { other sources-the use of television, video, posters, inter- } \\
\text { net and invited speakers to inform [14]. }\end{array}$ & $\begin{array}{l}\text { The women really appreciate the information about baby } \\
\text { and breastfeeding [8] [12] [14]. The conflicting information } \\
\text { causes lack of confidence on the conduct, increasing stress } \\
\text { on women [8] [14] [21]. The women receive little } \\
\text { information on postpartum recovery [15]. The lack of } \\
\text { in-formation affects negatively on women [10] [14] [15]. } \\
\text { The lack of information's a barrier to access puerperal } \\
\text { attention [21]. }\end{array}$ \\
\hline Communication & $\begin{array}{l}\text { Dialogic communication-professional talked/did not talk, } \\
\text { listened/did not listen to woman [9]-[14] [21]; } \\
\text { Informative communication-informed slowly/quickly, } \\
\text { clarified/limited to clarify, did not clarify doubts [12] [15] } \\
\text { [8]-[10] [21]; clarity of expression [9]; Feelings over } \\
\text { communication-woman fee at ease /embarrassed to talk } \\
\text { [9]-[13] [21]. }\end{array}$ & $\begin{array}{l}\text { The dialog strengthens the professional-woman confidence } \\
\text { [8] [9]. The dialog favors the identification of necessities } \\
\text { [9]. Clarifying and giving comfort are decisive aspects for } \\
\text { women's well being [12]. The professional's availability } \\
\text { expresses through a verbal and non-verbal communication } \\
\text { [9]. The lack of dialog restrains the rights of citizenship } \\
\text { [12]. The professional's listening ability development is a } \\
\text { priority to the puerperal attention [9] [10] [12] [15] [21]. }\end{array}$ \\
\hline $\begin{array}{l}\text { Attending } \\
\text { the necessities }\end{array}$ & $\begin{array}{l}\text { Specialized attention-only clinical attention [11]; } \\
\text { physical exam [12] [21]; pain medication [9] [12] [15]; lack } \\
\text { of orientation/emotional support [10] [11]; focusing on the } \\
\text { baby [9] [11] [12] [14] [21]; under estimated } \\
\text { multiparous-complaints/feelings [11] [12]; inattentive with } \\
\text { the primiparous [11] [15] [9] [10] [12]; general care for } \\
\text { baby [9] [21]; breastfeeding [9] [15]; only got informed } \\
\text { about breastfeeding [11]; discontinued relationship [8] [11]; } \\
\text { Resting-time for woman [9], ward routine restrained } \\
\text { resting [11] [15]; Public/private-greater quality in private } \\
\text { hospital [9] [10] [12] [21]; Primary attention-attention to } \\
\text { the puerperal at the station [8] [10] [21]; home assistance } \\
\text { [8] [10] [13]-[15]; inattentive with the primiparous [8] [10] } \\
\text { [21]; breastfeeding [8] [15]; only got informed about } \\
\text { breastfeeding [8]. }\end{array}$ & $\begin{array}{l}\text { People's necessities can differ from those identified by } \\
\text { professionals [13]. The puerperal care is based on regulated } \\
\text { necessities, the particular necessities should be redirected } \\
\text { to mother/baby [8]-[11] [13] [14] . The puerperal } \\
\text { woman-centered care is important to attend their necessities } \\
\text { [8] [10] [14] [15]. To decrease morbimortality, it is } \\
\text { necessary to identify the common complications earlier at } \\
\text { puerperium [12]. The technical competence perception and } \\
\text { the time availability are important for women to rely on } \\
\text { nurses [8]. The care for the primiparous should be priorized } \\
\text { [8] [10] [13]. Theattention at the primary level is a great } \\
\text { problem for the puerperal [8] [10]. Facing the inequalities } \\
\text { results in types of relation, social insertion and the primacy } \\
\text { of the scientific knowledge is more difficult for the } \\
\text { attended women at the public health service [12]. }\end{array}$ \\
\hline $\begin{array}{c}\text { Service } \\
\text { organization }\end{array}$ & $\begin{array}{l}\text { Infrastructure-few professionals [9] [10] [12]; insuffi- } \\
\text { cient clinic knowledge [12] [21] few hospital ladders; bed } \\
\text { sheets and absorbent; clothing [1]; Unit's routine-child in } \\
\text { nursery [11], visit [11] [15], lights on, noise, time for } \\
\text { procedures [15], nurse help [12]; Room sharing-noise, } \\
\text { without privacy [15]; support from other mothers [10] [12] } \\
\text { [14]; Food-quality and quantity [12] [15]; Leisure-lack } \\
\text { of television [12]; no space to stroll [12] [14]; } \\
\text { Environment-very warm ward [12]; Staff's } \\
\text { overload-very weary, pressured, stressed professionals } \\
\text { [8] [10] [11] [13] [15] [21]; Obstacles to access-attending } \\
\text { hours, long waiting periods, cost, misinformation, transport } \\
\text { [10] [14] [21]. }\end{array}$ & $\begin{array}{l}\text { A number of professionals relate to time spent in answering } \\
\text { demands and attending time, referring to the quality in care } \\
\text { [9] [10]. The primiparous does not have the courage to } \\
\text { protest against the inhuman hospital system [11]. The } \\
\text { inflexibility of the postpartum ward routine is the product } \\
\text { of an organization which prioritizes the staff's } \\
\text { convenience, disregarding the woman as the center of } \\
\text { attendance [15]. }\end{array}$ \\
\hline
\end{tabular}




\section{Continued}

\begin{tabular}{|c|c|c|}
\hline $\begin{array}{c}\text { Other } \\
\text { supports }\end{array}$ & $\begin{array}{l}\text { Other mothers-confidence, welcoming, care [1] [2] [4] } \\
\text { [5] [9]; dialoged, experiences shared [2] [4] [5]; help in the } \\
\text { ward, counseling, information and friendship [1] [2] [4] [5] } \\
\text { [8] [9]. Family-partners help with baby [1] [5] [6]; } \\
\text { sharing doubts [6]; mothers [8]; relatives and friends [6] } \\
\text { helping with the baby and house chores). }\end{array}$ & $\begin{array}{l}\text { The women build a solidary network among themselves to } \\
\text { encounter the lack of welcoming assistance and the } \\
\text { difficulty to attend their necessities [1]. Other mothers } \\
\text { propitiate emotional support and the situations in daily } \\
\text { practices [1] [2] [4] [5] [9]. The care given to other mothers } \\
\text { differ from the professionals care by reciprocity relation } \\
\text { [4]. The woman's emotional adaptation and social involve } \\
\text { family and friends support [5]. A network of family support } \\
\text { helps women to deal with their responsibilities at home [2] } \\
\text { [6]. }\end{array}$ \\
\hline
\end{tabular}

The way of treating was approved [8] [9] [11] [14] [15] or censored [8]-[12] [15] [21], observing the ability of the professionals in being attentive, sincere, empathetically and careful.

You got the impression that some midwives acted as if they were frozen or a robot [11].

The availability to attend considers the time of waiting and attending. In the immediate post-partum period, hospitalized women reported to promptly [8] [9] [14] [15] or taking too long [9] [10] [12] [15] [21] to be attended, discussing the professional's commitment to assist. There is no need to call someone because the nurses systematically would look at the puerperal/baby, awakening reassurance to women [11] [14] [15]. However, the professional's late arrival, after repeated requests or silence uneasiness, became more common the feelings of loneliness, helplessness and disrespect [9]-[12] [15] [21].

We could not call anyone because they would come with an ugly look on their faces [9].

Regardless of the care scenario, attending without haste represented an important characteristic to establish a relation of trust and friendlier communication with the professionals [8] [12] [14] [15]. However, hospitalized women mentioned the most about the time of attending, especially, to disapprove the professional's quickness [8]-[10] [12] [15]. While, in the same scenarios, other women complimented the time spent with themselves and their babies [8] [14] [15]. The puerperal perceived a greater duration of post-partum attendance at home [13].

I think people are just really friendly and helpful, and nothing else, you know, if you ask something it's no trouble at all [15].

The women [8]-[10] [12] [15] [21] pointed out the overload of work as one of the main obstacles in the interpersonal relationship. The interpersonal relationships affected the women's disposition to appeal in times of necessity, either because they felt at ease, fundamentally with the nurses [9], or were embarrassed to call the midwives [11] and nurses [10] [12].

\subsection{Information}

In this synthesis, the puerperal attributed great importance to the informative component on professional care. The guidelines, especially those relating to newborns, were perceived as determinants in the performance of self-confidence in a mother's role [9]. The information were directed to child's care: breastfeeding [8] [10] [11] [13] [14] [21], naval hygiene, bathing, change clothes [9] [13] [21] and childcare accomplishment [21].

There is quite a lot that they are teaching now and this is good for us [9].

Women have expressed satisfaction in two studies on hospital care, with informed content and professional competence [8] [9]. In a study on specialized outpatient care, the educational practices in groups were approved, improving on the information about exchanging experiences. This exchange allowed fears, necessities and solutions to practical problems to be shared [9], although, there was a lack of information on baby's general care [8] [10] [15], breastfeeding [12] [15], introduction to milk formulas [14], child's disease [10] [12] and prevention on child's disease [14].

If you are a first time mum, this is all new. And how often do you change her nappy? Or are you checking all the time [15]?

The value of the information given was evidenced, also when they reported unsatisfied necessities: lack of information [10]-[12] [14] [15] [21], absence of important content on the information received [8] [10] [11] [14] [21], insecurity on the professional's competence [8] [14] and contradicted information which made it difficult to decide on the conduct [8] [10] [14] [21], above all for the primipara [10] [11] [21].

One said this and the other midwife said that. It was a nuisance and maybe one of the reasons for the big problems with breastfeeding for the first time [11]. 
The scarcity on guidance related to women's health care was common [10] [12] [14] [15] [21]. Only in a study on professional home care [13], women said they had received information in dealing with the puerperal's emotional aspects.

We don't have a nurse to talk to and to tell us what to do. They don't provide us with the appropriate care. For example, when I had my period I went to the nurse in family planning and she told me to figure it out by myself without explaining anything [21].

In half of the studies, the puerperal would like to have received information about: post-partum prescribed medication [12]; care after surgical delivery discharge (washing of the abdomen, dressing, stitches withdrawal and continuation of daily activities) [15] [21]; reference services on puerperal complications [10] [15]; diet and exercise to return to the previous weight and how to find time for themselves [21]; completion of post-partum consult [14] [21]; resumption of sexual activity [21] and family planning [14] [21].

In two studies, the puerperal lamented the misinformation about the ward routine [11] [15], which adequately explained would provide a better recovery, mainly for the primipara [15]. Apart from all the limitations mentioned, there were women who felt privileged to have received some type of information they deemed important [8] [9] [15] [21].

\subsection{Communication}

In this synthesis, the characteristics on communicative practices perceived by the puerperal resulted in a worthwhile possibility of dialogical communication [9]-[14] [21] and the way of transmitting the information (informative communication) [8]-[10] [12] [14] [15] [21]. The perception of freedom to speak to a professional resulted in embarrassment: afraid to ask, to ask for help [9]-[12] [21] and to complain due to the lack of privacy [21] or confidence: feel at ease to talk [9] [11] [13] [21], and was influenced by the interpretation of interpersonal relationship and provision of information.

In few studies, the professional-woman communication involved conversation and listening, aiming to understand the puerperal experience and attend her needs, including emotionally [9] [11] [13]. In one of these facts, the difference among the professionals asking questions and talking to the women was established. This requires reciprocity of questioning and answering among themselves [9]. Often a dialog was an aspiration not succeeded, which acquired relevance by dissatisfaction originated in their absence, disregarding the diversity of expectations [9]-[12] [21]. The stereotyped perspective on midwives, who seemed to see the same needs in the every puerperal, it was found to be censured [11].

In the communicative process the women were more attentive to give information [8]-[10] [15] [21]. Also on this circumstance predominated a negative perception due to quickly informing and unwilling to clarify doubts (professional did not respond or responded superficially) [8]-[10] [12] [15] [21].

There is no communication between us and the health care providers. It is impossible that they respond to our questions [21].

In the same scenarios, other mothers expressed appreciation for the informative communication [8] [9] [15] [21]. The midwife provided more information when compared to the doctor [21]. The lectures addressed the hospitalized puerperal were very satisfied by the clarity of the language employed [9].

\subsection{Attending the Necessities}

In all the studies, women showed dissatisfaction with attending puerperium necessities, mainly by those who gave no attention to the primiparas (clinical complaints, support on maternal performance, provision of information) [8]-[11] [15] [21], focusing on the baby [9] [11] [12] [14] [12], lack of assistance at home [8] [10] [13] [14] and a nearby health unit [10], clinical approach fails in physical and emotional aspects [10] [12] [21], complaints of depreciation from multiparas [11] [12], lack of support [8] [15] or restricted observation on breastfeeding [8] [11] and relational discontinuity at the maternity [8]. In addition, the infirmary routine hindered resting and puerperal recovery [11] [15]. In their opinions, the access to private hospital service would have ensured higher quality assistance [9] [10] [12] [21].

And I just feel it would be nice to have something where you put your baby aside and: "Well, let's talk about you as a mother. And how are you feeling?” [14].

In parallel, half of the studies, the other puerperal felt that their necessities were satisfactory at a specialized hospital care [8] [9] [15] and ambulatory [21] as well as in the primary care [8] [13] [15]. The satisfaction above 
all, was the aid that provided time for themselves, pain treatment, supported for breastfeeding [9] [15], general baby care [9] [12], supported for maternal performance at home care [8] [13] [15] and relational continuity at the maternity [8].

The professionals' availability to attend was an important element for positive perception [8] [9] [14] [15] or negative [9] [10] [21].

\subsection{Service Organization}

The women in all the studies demonstrated the importance of service organization to attend the puerperal necessities [8] [13]. The overload work limiting the quality of care was one of the main factors. Most of the puerperas mentioned that the professionals were tired and stressed [8]-[11] [15] [21].

There was a moment that I felt a little bit of stress on behalf of the nurses and assistants [10].

Other negative aspects of the service organization cited by women were: infrastructure (lack of professionals, little clinical knowledge, lack of bed linen and clothing) [10] [12] [21]; the routine in the unit (child in the nursery, authorized people and the visiting duration, procedures before six o'clock in the morning, lights on and conversation late at night) [11] [12] [15]; sharing room (noise, lack of privacy) [15]. There was also dissatisfaction with a very hot ward [12], food [12] [15], lack of leisure [14] [15] and obstacles related to access service [14] [21] and public transportation [10].

The lights are turned on at half six in the morning [15].

The service organization was negatively evaluated, some of the women identified parts of the organizational characteristics had improved in attending the necessities, as the room was mostly cited which allowed them to have company and help other mothers [10] [12] [14]. They also liked the food [12] [15] and the largest number of professionals in the morning favored the readiness to attend [9] [12].

\subsection{Other Supports}

The dissatisfaction of needs in the post-partum strengthened the solidarity among the puerperas. In this review, the informal support most commented was offered by other mothers. The feeling of being cared for was awakened by trust, conversation and the exchange of information and advice, in addition to the small services in the ward (shared baby's diapers and woman's absorbents, gave medication, looking after the baby, got water, called the nurse) [9]-[12] [14]. In three studies [12]-[14], the waiting room was the most appreciated as the space for mutual support among the puerperas. Some relationships were maintained through the exchange of experiences by phone calls [10]-[12] [14].

Who is going to ask for (clothes, absorbents, medicine) are the others and what if something happens to them? When I felt bad, they got water for me; they were worried about me more than the nurses [12].

The partner help in taking care of the baby [8] [12] [14] and share their doubts [8]. The mothers [8] [10], sisters and friends [8] help with the baby and household chores.

\section{Discussion}

The themes identified in this review covering relational aspects, technical, informational, communicative, organizational and in society are inter-related and co-existed in women perception about puerperium care. However, in some thematic areas, superposition of common meanings and distinct were observed. In the attendance of necessities, women appreciated primary care [8] [10] [13]-[15], quality of private services [9] [10] [12] [21] and resting in the ward [9] [11] [15]. At the service organization, the women paid attention to the collective room [8] [10] [12], the food [12] [15] and leisure time [8] [12] as important care aspects. The service routine was also observed from the perspective of the daily ward routine [11] [15].

Some secondary interpretations, deepen in the reflection about complexity involving care, pointing out the differences in the needs perceived by women [15]; the importance to direct puerperal care basically guided by their necessities, the unique necessities for women/baby [8]-[11] [13]-[15], integrating technical competence with the ability to interact [9] [10] [12] [14] and dialogical communication [8]-[10] [12] [15] [21]; the negative repercussions on scarcity and information conflicts on the puerperal health [10] [14] [15] [21]; the overload on the professional as an important barrier for qualified care [8] [9] and informal support as an essential component for post-partum care [14]. 
From the primary and secondary synthesis, interpretations developed a "line of arguments" to reflect on the main health care dimensions for the puerperal. The model goes from an individual dimension to a social dimension, assuming that there are multiple connections among various dimensions that interpenetrate each other, producing a complex network of contact points and possibilities [22].

The personal expectations of care reveal the desirable attributes for the health services to assist the puerperal [22] [23]. In this synthesis, hoping for recognition of the singularity of their necessities, the women emphasized the appreciation on the interactive components and the communicative practices in health, disregarding skills and technical knowledge from the professional providing important information and responding to the needs of physical and mental health. However, the inadequacy between the care of the centered professional offered by services and centered care on a woman chosen by them resulted in a great dissatisfaction. The chosen scale of values can influence the perception of each one [24], the low expectations from puerperas on the quality of public health services may have favored in some situations, a more positive view on post-partum care.

The appreciation of the distinct components on care by professionals and women are suggestive in different studies [13] [25]. The puerperal necessities may differ from those identified by the professionals and, on the other hand, the professionals expectations are connected to the centered professional care: the patient depends on the professionals' judgment and ideas, participating little in the decisions about their own health [26] [27].

The construction of solidarity networks in dealing with daily necessities is part of life, assuming the different importance according to the situation experienced by the people. These networks are essential components of social and emotional adaptation to the puerperal, in health services and households [8] [13] [14]. In the current synthesis, the maternity was the main care scenario and women appreciated very much on solidary relations established in the ward in search of emotional support and the practical situations of everyday life, to deal with the lack of a warm welcoming and the difficulty of attending their necessities [9] [11]-[14]. The care resulting from other mothers differs from the professional care due to the reciprocity of the relationship and the mutuality in caring [11]. In the transition from the hospital to home, the family support becomes more important mainly provided by their partners and mothers [8]. Note that, addressing the informal support, women contrasted positive attributes [8]-[14].

The professional care sphere refers to meeting professional-woman, involving technical and scientific knowledge and relational and communicative abilities, which enable the professional to find appropriate responses to concrete situation [23]. In all studies, this meeting, especially within the service, was deeply affected by the little time available to attend. The hurry to attend, reinforced women's perception of disregarding their necessities, especially emotionally and reproductively, even when they were not secure on their technical competence and, often, suffered and felt vulnerable with the impersonality of the relation between them [9]-[12] [14]. They liked the devoted care given to the children, but deplored the disregarding to the women. There was a different expectation of primipara care, without neglecting the multiparas [9]-[12] [15] [21].

The organizational sphere affects the processes of articulation in technical and managerial fields to ensure access in care, according to each person's health needs [23]. The dissatisfaction of the rules in the ward routine, the organization tends to prioritize the convenience of the team [15], showing disagreements between rationality of the services and the puerperal's necessities. Despite the technical primacy [11] [12] [15], conflicts of information in the same team caused by insecurity and stress involving puerperal care [8] [10] [11] [14] [21]. It should be noted that the dialog among the technical standards and the assumptions and the subject's expectations is essential to enlarge the possibilities of more adequate answers in relation to health needs [23] [28].

The limitations on work conditions were widely mentioned, highlighting the overload of work due to lack of staff, superposition of tasks and excess of demands. The overload of work is perceived as an important barrier for the quality in care [8] [9] [11] [13] [15] [21] and is one of the main predictors of burnout: a response to persistent labor stress perceived when the strategies to coping with stress are ineffective [29]. Burnout has diversified consequences on the physical and mental health and the quality of work [30] [31].

The facility of obtaining the required health care, resulting characteristics service of the health resources and from the population translating the accessibility to health services, which is an essential component to the quality of attention [32]. This synthesis revealed organizational obstacles to access health services, becoming the most relevant in the lack of formal connections between the levels of complexity which has been committed particularly assisting primary care [8] [10] [13]-[15] [21].

The puerperium health care carries the traces of social conditions of its production, being conditioned by structured social contexts which conclude: 1) The appreciation of social private health providers in the field of 
inequalities to access goods and services, as well as in women's view, lack of financial resources has prevented no access to qualified care [9] [10] [12] [21]; 2) The historical-cultural idealization of "maternal love" as a symbol of the feminine identity, which "naturalizes" the primacy of the baby's needs to detriment women, reiterated in health practice [33]; 3) The inequalities in professional-woman relation founded the prioritization of technical-scientific knowledge, disregarding the subjectivity and intersubjectivity of the puerperium's interpretations [5] [23] [28]; 4) The puerperium's low appreciation in public health policies, in comparison to other stages of the puerperal pregnancy cycle [21].

In this synthesis, the diversity of voices expressed distinct and agreeable needs and expectations on many aspects involving the quality of care. Therefore, it is essential to understand the ideas and feelings of women to achieve a comprehensive care through the development of health practices appreciating the women's needs without underestimating the attention due to the baby. The mother and son's necessities preserve the specificity, although inter-related in this period of life. To perform research on the women and professionals' perspective in multiple contexts of life and work, certainly, will contribute to greater reciprocity among the needs of those involved and the organization and the production of health care to the puerperium.

\section{Considerations and Limitations of the Study}

In applying the results to this review, there should be some consideration to the peculiarities of the included articles: First, most had the maternity as a care scenario, which may explain the over appreciation on the support received from other mothers. Second, almost all the women received care in public health services and may be more affected by bias of gratitude and by the fear of losing their rights to the service. Third, the participants' experiences must have been influenced by the characteristics of the health care systems in which the services were integral parts, but, in spite of the contexts diversity, it was possible to build a network of information which provides a greater understanding of the phenomenon.

\section{References}

[1] Welch, L.G. and Miller, L.A. (2008) Emotional and Eduacational Components of Pregnancy. The Global Library of Women's Medicine.

http://www.glowm.com/section view/heading/Emotional\%20and\%20Educational\%20Components\%20of\%20Pregnan cy/item/414

[2] Cabral, F.B. and Oliveira, D.L.L.C. (2010) Women's Vulnerability in the Puerperium from the View of Family Health Teams: Emphasis on Generational Aspects and Adolescence. Revista da Escola de Enfermagem da USP, 44, 366-372.

[3] Silva, F.C.S., Araújo, T.M., Araújo, M.F.M., Carvalho, C.M.L. and Caetano, J.A. (2010) Postpartum Depression in Puerperal Women: Knowing the Interactions among Mother, Son and Family. Acta Paulista de Enfermagem, 23, 411-416. http://dx.doi.org/10.1590/S0103-21002010000300016

[4] Barry, C.A., Stevensona, F.A., Brittena, N., Barberb, N. and Bradleyc, C.P. (2001) Giving Voice to the Lifeworld. More Humane, More Effective Medical Care? A Qualitative Study of Doctor-Patient Communication in General Practice. Social Science \& Medicine, 53, 487-505. http://dx.doi.org/10.1016/S0277-9536(00)00351-8

[5] Unger, M.P. (2005) Intersubjectivity, Hermeneutics, and the Production of Knowledge in Qualitative Mennonite Scholarship. International Journal of Qualitative Methods, 4, September 2005. http://www.ualberta.ca/ iiqm/backissues/4 3/pdf/Unger.pdf

[6] Noblit, G.W. and Hare, R.D. (1988) Meta-Ethnography: Synthesizing Qualitative Studies. London: Sage, Newbury Park.

[7] Tong, A., Sainsbury, P. and Craig, J. (2007) Consolidated Criteria for Reporting Qualitative Research (COREQ): A 32-Item Checklist for Interviews and Focus Groups. International Journal for Quality in Health Care, 19, 349-357. http://dx.doi.org/10.1093/intqhc/mzm042

[8] Frei, I.A. and Mander, R. (2011) The Relationship Between First-Time Mothers and Care Providers in the Early Postnatal Phase: An Ethnographic Study in a Swiss Postnatal Unit. Midwifery, 27, 716-722. http://dx.doi.org/10.1016/j.midw.2009.11.004

[9] Soares, A.V.N. and Silva, I.A. (2003) Mothers' Representation Concerning the Rooming-In: From the Abandonment to the Acceptance. Revista da Escola de Enfermagem da USP, 37, 72-80. http://dx.doi.org/10.1590/S0080-62342003000200009

[10] Rodrigues, D.P., Fernandes, A.F.P., Silva, R.M. and Rodrigues, M.S. (2006) The Home as Educational Space for Self Care of Puerperas: Mother-Child Binomial. Texto \& Contexto Enfermagem, 15, 277-286.

[11] Bondas-Salonen, T.J. (1998) New Mothers’ Experiences of Postpartum Care-A Phenomenological Follow-Up Study. 
Journal of Clinical Nursing, 7, 165-174. http://dx.doi.org/10.1111/j.1365-2702.1998.00138.x

[12] Almeida, M.S. and Silva, I.A. (2008) Women’s Needs in Immediate Puerperium in a Public Maternity in Salvador, Bahia, Brazil. Revista da Escola de Enfermagem da USP, 42, 347-354. http://dx.doi.org/10.1590/S0080-62342008000200019

[13] Bailey, S. (2010) Postnatal Care: Exploring the Views of First-Time Mothers. Community Practitioner, 83, $26-29$.

[14] Butchart, W.A., Tancred, B.L. and Wildman, N. (1999) Listening to Women: Focus Group Discussions of What Women Want from Postnatal Care. Curationis, 22, 3-8. http://dx.doi.org/10.4102/curationis.v22i4.739

[15] Beake, S., Rose, V., Bick, D., Weavers, A. and Wray, J. (2010) A Qualitative Study of the Experiences and Expectations of Women Receiving In-Patient Postnatal Care in one English Maternity Unit. BMC Pregnancy and Childbirth, 10, 70. http://dx.doi.org/10.1186/1471-2393-10-70

[16] Sandelowski, M. and Barroso, J. (2007) Handbook for Synthesizing Qualitative Research. Springer Publishing Company, New York.

[17] Campbell, R., Pound, P., Morgan, M., Daker-White, G., Britten, N., Pill, R., Yardley, L., Pope, C. and Donovan, J. (2011) Evaluating Meta-Ethnography: Systematic Analysis and Synthesis of Qualitative Research. Health Technology Assessment, 15, 1-164.

[18] Atkins, S., Lewin, S., Smith, H., Engel, M., Fretheim, A. and Volmink, J. (2008) Conducting a Meta-Ethnography of Qualitative Literature: Lessons Learnt. BMC Medical Research Methodology, 8, 21. http://dx.doi.org/10.1186/1471-2288-8-21

[19] Monforte-Royo, C., Villavicencio-Chavez, C., Tomás-Sábado, J., Mahtani-Chugani, V. and Balaguer, A. (2012) What Lies behind the Wish to Hasten Death? A Systematic Review and Meta-Ethnography from the Perspective of Patients. PLoS ONE, 7, Article ID: e37117. http://dx.doi.org/10.1371/journal.pone.0037117

[20] Waibel, S., Henao, D., Aller, M.B., Vargas, I. and Vázquez, M.L. (2012) What Do We Know About Patients’ Perceptions of Continuity of Care? A Meta-Synthesis of Qualitative Studies. International Journal for Quality in Health Care, 24, 39-48. http://dx.doi.org/10.1093/intqhc/mzr068

[21] Khalaf, I.A., Abu-Moghli, F.A., Mahadeen, A.I., Callister, L.C. and Al-Hadidi, M. (2007) Jordanian Women’s Perceptions of Post-Partum Health Care. International Nursing Review, 54, 288-294. http://dx.doi.org/10.1111/j.1466-7657.2007.00559.x

[22] Cecilio, L.C.O. (2011) Theoretical and Conceptual Notes on Evaluative Processes Taking the Multiple Dimensions of Healthcare Management into Account. Interface-Comunicação, Saúde, Educação, 15, 589-599. http://dx.doi.org/10.1590/S1414-32832011000200021

[23] Ayres, J.R.C.M. (2009) Organization of Health Care Actions: Models and Practices. Saúde e Sociedade, 18, 11-23. http://dx.doi.org/10.1590/S0104-12902009000600003

[24] Assefa, F., Mosse, A. and Hailemichael, Y. (2011) Assessment of Clients' Satisfaction with Health Service Deliveries at Jimma University Specialized Hospital. Ethiopian Journal of Health Sciences, 21, 101-109.

[25] Ayres, J.R.C.M. (2007) A Hermeneutic Conception of Health. Phyisis: Revista de Saúde Coletiva, 17, 43-62. http://www.scielo.br/pdf/physis/v17n1/v17n1a04.pdf

[26] Roter, D.L. and Hall, J.A. (2004) Physician Gender and Patient-Centered Communication: A Critical Review of Empirical Research. Annual Review of Public Health, 25, 497-519. http://dx.doi.org/10.1146/annurev.publhealth.25.101802.123134

[27] Bensing, J.M., Tromp, F., Dulmen, S., Brink-Muinen, A., Verheul, W. and Schellevis, F.G. (2006) Shifts in DoctorPatient Communication between 1986 and 2002: A Study of Videotaped General Practice Consultations with Hypertension Patients. BMC Family Practice, 7, 62. http://dx.doi.org/10.1186/1471-2296-7-62

[28] Reisberg, M. (1996) Customer Satisfaction in Health Care. http://www.asha.org/uploadedFiles/aud/CustSat11v6n2.pdf

[29] Leiter, M.P., Frank, E. and Matheso, T.J. (2009) Demands, Values, and Burnout. Canadian Family Physician, 55, 1224-1230.

[30] Harnois, G. and Gabriel, P. (2000) Mental Health and Work: Impact, Issues and Good Practices. World Health Organization/International Labour Organisation. http://digitalcommons.ilr.cornell.edu/cgi/viewcontent.cgi?article=1223\&context=gladnetcollect

[31] Ruiz, C.O. and Rios, F.L. (2004) El Burnout o Síndrome de Estar Quemado en los Profesionales Sanitarios: Revisión y Perspectivas. International Journal of Clinical and Health Psychology, 4, 137-160.

[32] Feliciano, K.V.O., Kovacs, M.H. and Sarinho, S.W. (2005) Feelings of Paediatric Emergency Service Professionals: Reflexions on Burnout. Revista Brasileira de Saúde Materno Infantil, 5, 319-328. http://dx.doi.org/10.1590/S1519-38292005000300008

[33] Donabedian, A.A. (1990) The Seven Pillars of Quality. Archives of Pathology \& Laboratory Medicine, 114, 11151118. 